\title{
Student's Perception of Web 2.0 Tools and Educational Applications
}

\author{
https://doi.org/10.3991/ijet.v15i23.19065 \\ Zehra Ozcinar ${ }^{(凶)}$ \\ Ataturk Teacher Training Academy, North Cyprus, Turkey \\ zehra.ozcinareaoa.edu.tr \\ Regina G. Sakhieva \\ Kazan Federal University, Kazan, Russia \\ Elena L. Pozharskaya \\ Plekhanov Russian University of Economics, Moscow, Russia \\ Olga V. Popova \\ Financial University under the Government of the Russian Federation, \\ Moscow, Russia \\ Mariya V. Melnik \\ I.M. Sechenov First Moscow Medical University, Moscow, Russia \\ Valentin V. Matvienko \\ Peoples' Friendship University of Russia, Moscow, Russia
}

\begin{abstract}
The information technology used to acquire the skills determined as 21 st-century competencies in the education-training process to individuals is increasing rapidly. Nowadays, Web 2.0 tools are increasingly used. Effective use of Web 2.0 tools, which are widely used in daily life, by students and teachers in education are also on the list. Effective use of assistive technologies by teachers depends on their attitudes towards assistive technologies. To increase their success, they use these technologies in activities held in the classroom. In the study, it was aimed to determine the attitudes of teachers and student candidates towards the use of assistive technology. A case study approach constituted the methodological framework of this study. This study was conducted in the fall semester of 2019-2020 with 42 students. Teachers and student's obligation to take "instructional technology and material design course" was hence initiated as a result. Numerous Web 2.0 tools were reminded to the students for the results of the research. The data of this study were collected through open-ended questions developed by the researchers to define the opinions of the students regarding Web 2.0 tools and educational practices that they will encounter in their future professional lives. Content analysis, frequency and percentage was applied in the analysis of data. The analysis of data was sought to answer the following questions; (1) How often did teachers and students use web 2.0 tools?; (2) What are Web 2.0 tools that teachers and students use or plan to use in their current and future teaching profession?; (3)
\end{abstract}


What are the reasons for teachers and students to use Web 2.0 tools as teachers in their professional lives?; (4) What are teacher education students' views on Web 3.0 technologies and (5) What are the changes and innovations these technologies will bring in the field of education?

Keywords-Teacher candidate; technology; WEB 2.0; education, Applications

\section{Introduction}

In the current environment of technological and social change, significant transformations are underway in terms of how we live and work. We refer to contemporary times as the "information age" or "knowledge-based society", characterized by the spread of information and communication technologies (ICT) and the growing demand for new educational approaches and pedagogies that promote lifelong learning in the current environment of technological and social changes [16,35,34].

Technology, which is a part of our daily life, makes itself felt in every area of our lives. Due to the convenience that technology has brought to the everyday life of people, many people use technology effectively in many environments such as schools, homes and workplaces. It has been done in many studies with the use of technology in every field. It is supported by the use of technological tools in all areas of education, the effectiveness of these tools, and the conflicts that affect the motivation levels $[14,32,12,33]$.

In the field of higher education, there have been rapid changes in the views on what education is. The question is not only about the development of knowledge, but also about the development of skills and resources which are equally necessary to bring a social and technological change resulting into a continuous lifelong learning [37][29]. Regarding ICT, we witness the rapid expansion and spread of technologies that are not related to "narrow publishing" and focus on building communities where people come together to collaborate, learn and create information.

The concept of Web 2.0 is a term originally used by Darcy DiNucci in the article "Fragmented Future" [13]. Tim O'Reilly later voiced it during a conference O'Reilly, [28]. Despite multiple interpretations of the term "Web 2.0", we define it as a more personalized, communicative form of world wide web. Participation, connection, collaboration and sharing of information and ideas among users is an innate part of it. Since Web 2.0 goes beyond its older versions, this is also called "Reading-Writing Web" [22] where the viewable/downloadable content allows the general public to actively contribute and shape the content. Web 2.0 applications, includes, but are not limited to, blogs, wikis, really simple syndications (RSS), podcasts, social networking sites, tag-based folksonomies, and peer-to-peer (P2P) media sharing utilities [3,18].

It seems that today's students have significant potential in meeting their needs and developing learning experiences through rich opportunities for personalization, networking and collaboration [37,38] among many commentators about the Web 2.0 phenomenon. He claims that socialization has the potential to increase education. He 
believes that these aspects can support three components or activities that characterize learner-centred instruction:

\author{
i. Support for speech interaction \\ ii. Support for social feedback \\ iii. Support for relationships between social networks and people
}

Web 2.0 technologies have been summarized by socially based tools and systems, collectively called "social software". At the point reached today, the support of mobile technologies such as smartphones, tablets and iPods with powerful advanced softwares that have met the expectations of internet users. Especially with the development of Web 3.0 technologies, web pages offer different content specific to each internet user. In parallel with the development of today's internet technologies, bandwidth and data volume capacity are increasing. This eliminates the obstacle in front of video sharing sites, making it easier to access and share videos on the internet quickly [27]. With the ever-increasing number of users, today's video sharing sites are among the most visited places in the world [7]. Video sharing sites not only increase the number of existing users thanks to their integration with Android and IOS based mobile devices, which have become widespread recently but also offer their users the freedom of movement.

Assistive technologies can be examined under three sub-titles: low level (nontechnological), medium level and high (advanced) technological tools [10,30,31,25]. Education can change with the use of Web 2.0 tools as these supports individual learning and allow students to collaborate [20,21]. Web 2.0 tools are used in the educational context in order to engage students in their learning while providing social interaction with their peers as part of the learning process, to develop a deep understanding of content, and to allow students opportunities for. Low-level technologies; are vehicles that are easily supplied and cost-effective. For example, for a student whose finger muscles are insufficient to hold a pen, a pen-mounted tool known as 'pen corners' (PECS) is used in the education of children with autism. Intermediate technologies include electronic devices. Voice recorders, talking calculators, can be given as examples in this group. There are more computer technology-based products in high-end technologies. However, these tools are more complicated to use than low and medium technological tools. Therefore, training on the use of these tools is required [15]. In studies examining attitudes towards assistive technologies, it is seen that teachers' attitudes are mostly positive $[17,26,19,23,25]$.

\title{
1.1 Purpose of the study and research questions
}

Given the rationale above, the purpose of this study is to explore the effect of the ITMD course on the perceptions of Primary school teacher education students' candidates' content development competencies with web 2.0 tools and the necessity of these tools.

Based on the purpose, the following research questions are posed: 
Question 1: How often do you use WEB 2.0 tools?

Question 2: What are your thoughts on the use of Web 2.0 technologies in education?

Question 3: Which Web 2.0 technology do you most want to use in your professional life (teaching profession)?

Question 4: What are your reasons for preferring this? \& What are your thoughts on the usage of Web 2.0 technologies? Why?

Question 5: What are your views on Web 3.0 technologies? What changes (positive or negative) in education might you foresee in the future with Web 3.0 technology?

\section{$2 \quad$ Methodology Used}

The research is a descriptive study and was carried out by the interview method, which is one of the qualitative research methods [5,39]. Hennink, Hutter, \& Bailey [40] stated that qualitative research is a research model that helps us to understand the participants' perspectives on a situation or a subject and their comments on the subject.

\subsection{Research group}

A case study approach constitutes the methodological framework of this study. This study was conducted in the fall semester of 2019-2020 with 42 primary school faculty students. The Primary school students' obligation to take "instructional technology and material design course". Numerous Web 2.0 tools to be learned for the results of the research were reminded to the students. The data of this study were collected through open-ended questions developed by the researcher to define the opinions of the students regarding Web 2.0 tools and educational practices that they will encounter in their future professional lives.

Table 1. Demographic information of the instructors

\begin{tabular}{|l|l|c|c|}
\hline & & No. & \% \\
\hline \multirow{4}{*}{ Gender } & Female & 25 & 40 \\
\cline { 2 - 4 } & Male & 17 & 60 \\
\cline { 2 - 4 } & Total & 42 & 100 \\
\hline \multirow{4}{*}{ Age } & $18-20$ & 8 & 50 \\
\cline { 2 - 4 } & $21-25$ & 20 & 40 \\
\cline { 2 - 4 } & 26 and over & 14 & 10 \\
\cline { 2 - 4 } & Total & 42 & 100 \\
\hline \multirow{3}{*}{$\begin{array}{l}\text { Using Weriods } \\
\text { peb 2.0 Tools }\end{array}$} & 1 year & 12 & 20 \\
\cline { 2 - 4 } & 2-5year & 21 & 10 \\
\cline { 2 - 4 } & 6 and more years & 10 & 100 \\
\cline { 2 - 4 } & Total & 9 & \\
\hline
\end{tabular}




\subsection{Data collection tools}

In this research, the demographic information form developed by the researchers and a semi-structured questionnaire consisting of open-ended questions were used as data collection tools. The demographic information form was used to determine the demographic characteristics of primary school students. In contrast, the questionnaire was used to determine the opinions of the primary school students about Web 2.0 tools. Open-ended questions in the questionnaire were created by making use of the literature and the researchers' own experiences. The questionnaire was first examined by five experts who are experienced in qualitative research, and necessary corrections were made according to the feedback from them. The questionnaire form was applied to four instructors outside the study group for pilot implementation in this state, and it was checked whether the questions were understandable.

\subsection{Data analysis}

The data obtained from open-ended questions were analysed by content analysis method. While investigating the content, it was aimed to bring together the data similar to each other within the framework of certain concepts and themes and to organize them in a way that the reader could understand. NVivo 11' program, a computer-aided qualitative data analysis program, was used in data analysis, and an inductive approach was adopted during content analysis. The classroom teacher department analysed the answers given by the senior students to the questions and codes were created with the participants' expressions with the in-vivo code generation feature of the NVivo program. Then, the appropriate themes containing common codes were determined by the researchers to include similar principles, and the regulations were collected under these themes.

\section{Results}

\subsection{How often do you use WEB 2.0 tools? Findings related to the question}

Table 2. How often do you use WEB 2.0 tools?

\begin{tabular}{|l|c|}
\hline & No. \\
\hline One or Several Days a Month & 2 \\
\hline One or Several Days a Week & 10 \\
\hline Everyday & 30 \\
\hline Total & 42 \\
\hline
\end{tabular}

In today's technology age, when Table 2 was examined, 10 Senior students of primary school teaching department of the classroom used Web 2.0 tools once or more. There are quite a few 30 primary school department last classes student candidates who express their service every day. Besides, they stated that the two Senior students of primary school teaching department students used one or more 
times a month. This situation is quite surprising. The students who use it once or several times a month are asked the following question. Are you not using social communication tools such as Facebook, Instagram, Twitter, among Web 2.0 tools? The answer to this question is similar in both students. They stated that they found social media usage tools unnecessary, and they did not have an account.

3.2 What are your thoughts on the use of Web 2.0 technologies in education? Findings related to the question

Table 3. What are your thoughts on the use of Web 2.0 technologies in education?

\begin{tabular}{|l|c|l|c|}
\hline & $\mathbf{N}$ & & $\mathbf{N}$ \\
\hline \multirow{4}{*}{ Intend to use } & \multirow{3}{*}{41} & Make a presentation & 28 \\
\cline { 3 - 4 } & & Doing an event & 27 \\
\cline { 3 - 4 } & & Assessment and evaluation & 12 \\
\cline { 3 - 4 } Don't think of using & \multirow{2}{*}{1} & Sharing information & 8 \\
\hline & & I do not need & 1 \\
\hline
\end{tabular}

As can be seen in Table 3, when it was asked "what do you think about the using of Web 2.0 tools? 41 students stated that they intended to use it. However, 1 of the students stated that he didn't intend to use it. When asked why he said that he did not feel the need of using it. Students who were thinking about using Web 2.0 tools on education were asked where did they like to use it. 28 students said that they liked to use it while doing presentations. Also, 27 students stated that they wanted to use web 2.0 tools while doing activities and that they would reinforce their learning with this technique.

\subsection{Which Web 2.0 technology do you most want to use in your professional life (teaching profession)? Findings related to the question}

Table 4. Which Web 2.0 technology do you most want to use in your professional life (teaching profession)

\begin{tabular}{|l|l|c|}
\hline & & \multicolumn{1}{|c|}{ n } \\
\hline \multirow{5}{*}{ Hardware } & Projection & 38 \\
\cline { 2 - 3 } & Mobile / Cell phone / Smartphone / Android & 21 \\
\cline { 2 - 3 } & Smartboard & 20 \\
\hline \multirow{5}{*}{ Web 2.0 tools } & Presentation Programs & 38 \\
\cline { 2 - 3 } & Virtual learning environments & 11 \\
\cline { 2 - 3 } & Educational Animation & 10 \\
\cline { 2 - 3 } & Online tests & 9 \\
\cline { 2 - 3 } & Kahoot & 2 \\
\cline { 2 - 3 } & Simulation & 1 \\
\cline { 2 - 3 } & Digital storytelling & 1 \\
\hline
\end{tabular}


We presented the question of which Web 2.0 technology they want to use most in their professional life (teaching profession) in two headings. We asked the students to explain the hardware and web 2.0 tools. They stated that they wanted to use the most projection equipment in terms of hardware. Also, students who wished to use the projection device said that they wanted to use their mobile phones and smartboard tools in their education. The classroom teacher department stated that last year students wanted to use the presentation programs the most from Web 2.0 programs. The number of students who wished to use virtual learning environments was also quite high. The remarkable point in the findings of this question was that students from the new generation learning technology programs did not respond. Only two people wanted to use 'Kahoot' in education.

\subsection{What are your reasons for preferring this? \& What are your thoughts on the usage of Web 2.0 technologies? Why? Findings related to the question}

Table 5. What are your reasons for preferring this? \& What are your thoughts on the usage of Web 2.0 technologies?

\begin{tabular}{|l|c|}
\hline & No. \\
\hline Attention & 35 \\
\hline Interactive education & 26 \\
\hline Fast, easy access & 18 \\
\hline Cooperative Learning & 7 \\
\hline Student active & 3 \\
\hline Total & 40 \\
\hline
\end{tabular}

From the findings of the primary faculty student candidates about the reasons for using WEB 2.0 tools, most of the students stated that they wanted to use these technological tools for attention (No.=35). Senior students of primary school teaching department indicated that they wanted to use web 2.0 tools in their education as they provided interactive teaching. Three Senior students of primary school teaching department stated that they would use it in their knowledge due to its being the student-centred approach. 
3.5 What are your views on Web 3.0 technologies? What changes (positive or negative) in education might you foresee in the future with Web 3.0 technology? Findings related to the question

Table 6. What are your views on Web 3.0 technologies? What changes (positive or negative) in education might you foresee in the future with Web 3.0 technology?

\begin{tabular}{|l|l|c|}
\hline & & \multicolumn{1}{|c|}{ No. } \\
\hline \multirow{5}{*}{ Advantage } & Accessing information faster & 31 \\
\cline { 2 - 3 } & Computers will help people / human life make it easier & 20 \\
\cline { 2 - 3 } & Getting information independent of time and resources & 12 \\
\cline { 2 - 3 } & Storing/transferring more information & 10 \\
\cline { 2 - 3 } & Increasing creativity & 9 \\
\cline { 2 - 3 } & & 22 \\
\hline \multirow{5}{*}{ Disadvantage } & Lazy student / ready to put on / passivation & 11 \\
\cline { 2 - 3 } & Technology addiction & 5 \\
\cline { 2 - 3 } & No need for teachers & 2 \\
\cline { 2 - 3 } & Decreasing psychomotor skills & \\
\hline
\end{tabular}

Opinions on the Web 3.0 question were gathered under two headings. Advantages and disadvantages. In its benefits, many Senior students of primary school teaching department stated that they would provide instant access to information (No.=31). They said that individuals could access information whenever they wanted with the technological devices they have. They stated that computers and technological devices would make people's lives easier. From the opinions of Senior students of primary school teaching department about the disadvantages of senior students of primary school teaching department about web 3.0 tools, they regarded incident access to information as a disadvantage as it would provide lazy students, easy access, learning from research and practice.

On the other hand, 5 student candidates stated that information can be accessed without the need for a student since the data can be accessed instantly as a disadvantage as. Primary school teacher faculty students stated that web 3.0 tools would bring technology addiction which would make one feel tense and emptiness when one would stay away from your computer. They indicated that it might affect students psychologically. Two student candidates see it as a disadvantage due to its decreased psychomotor skills.

\section{Discussion and Conclusion}

In the results of the first finding, 30 Senior students of primary school teaching department expressed their daily use in the opinions of Senior students of primary school teaching department about the frequency of using Web 2.0 tools. Also, they stated that two Senior students of primary school teaching department used it one or more times a month. This number is very low. It is surprising when two Senior students of primary school teaching department indicated that they did not use social media. As a result of this research, Horzum [42] shows similarities with the data 
obtained when looking at the frequency of using WEB 2.0 tools. When the technological age was taken into consideration, and awareness of the existence of Web 1.0 tools increased the rate of use of Web 2.0 tools.

In the results of the "What do you think about the training of Web 2.0 tools" findings, 41 final students stated that they intended to use. However, one student noted that he didn't need it. Students who were thinking about using Web 2.0 tools in education were asked where they would like to use it. 28 students said that they needed and would use while giving a presentation. Also, 27 students stated that they wanted to use web 2.0 tools while doing activities and that they would reinforce their learning with this technique. This result is quite good. This finding supports a similar research conducted with the participation of lecturers in different universities $[23,1,2,11,32]$.

Two headings were used to show which Web 2.0 technology they would like to use most in their professional life (teaching profession). We asked the students to explain the hardware and web 2.0 tools. In the results, it was concluded that they wanted to use projection equipment the most in terms of hardware. They also stated that they wanted to use the projection device, their mobile phones and smartboard tools in their education. The number of students who wished to use virtual learning environments is also quite high. The striking point in the findings of this question is that students from the new generation learning technology programs do not respond. Only two people who wanted to use 'Kahoot' in their teaching. Korucu \& Cakir [41] concluded that teachers wanted to use Facebook, Prezi, Powtoon, Videocast, Social networks, Blog, Google tools, measurement and evaluation tools. They concluded that faculty members did not intend to use tools such as Wiki and Podcast $[9,10]$.

As a result of the findings of Senior students of primary school teaching department candidates about the reasons for using WEB 2.0 tools, it was concluded that most of the students wanted to use these technological tools for attention. It was supposed that student candidates wished to use web 2.0 tools in their education while providing interactive teaching. This finding is similar to the results of many studies $[35,36,6,4,8]$.

The results in the Web 3.0 question were gathered under two headings. Advantages and disadvantages. It was concluded that many prospective teachers, seem to have an advantage because they will have instant access to information. They have stated web 3.0 tools as an advantage for computers and technological devices to make people's lives easier. Senior students of primary school teaching department regarding the disadvantages of senior student candidates on web 3.0 tools, they evaluated access to events as a disadvantage that would enable lazy students to learn from easy access, research and practice.

On the other hand, the opinions of 5 senior students of primary school teaching candidates were considered as a disadvantage because the information can be accessed without the need for a teacher. After all, the data can be accessed immediately. Senior students of primary school teaching department stated that web 3.0 tools would bring technology addiction which would make one feel nervous and empty when one stayed away from your computer. Two senior students of primary school teaching department see this as a disadvantage due toits decreased 
psychomotor skills. When all the results were analysed, it was concluded that the senior students of primary school teaching department knowledge of technology was at a sufficient level, but they had problems in adapting to education. For this reason, prospective teachers can be given more information in terms of integrating technology into instruction, technology design lessons can be added, in-service training can be provided, and technology-supported curriculum lessons can be added as elective courses.

\section{Acknowledgements}

1. The work was performed according to the Russian Government Program of Competitive Growth of Kazan Federal University.

2. The work was performed according to the Program of Development of Financial University under the Government of the Russian Federation for 2020.

3. The work was performed according to the project of improving competitiveness of the leading Russian universities among the leading world scientific education centres "5-100" of First Moscow State Medical University.

4. The publication has been prepared with the support of the RUDN University Program 5-100.

\section{$6 \quad$ References}

[1] Ahmed, A. M., AbdelAlmuniem, A., \& Almabhouh, A. A. (2016). The current use of Web 2.0 tools in university teaching from the perspective of faculty members at the college of education. International Journal of Instruction, 9(1): 179-194. https://doi.org/10.12973/iji. 2016.9114a

[2] Ajjan, H., \& Hartshorne, R. (2008). Investigating faculty decisions to adopt Web 2.0 technologies: Theory and empirical tests. The Internet and Higher Education, 11: 71-80. https://doi.org/10.1016/j.iheduc.2008.05.002

[3] Alexander, B. (2006). Web 2.0: A new wave of innovation for teaching and Learning? EDUCAUSE Review, 41(2): 32-44. http://www.educause.edu/ir/library/pdf/erm0621.pdf

[4] Ardley, J., \& Repaskey, L. (2019). Video Annotated Technology: Exploring Teacher Candidates' Adaptation to a New Tool in Student Teaching. i-Manager's Journal of Educational Technology, 16(2): 35.

[5] Buldu, D., \& Armagan, F. (2019). Determination of the opinions of prospective science teachers about the planned trip to the sugar factory. International Journal of Innovative Research in Education, 6(2): 21-39. https://doi.org/10.18844/ijire.v6i2.4474

[6] Caliskan, S., Guney, Z., Sakhieva, R. G., Vasbieva, D. G., \& Zaitseva, N. A. (2019). Teachers' Views on the Availability of Web 2.0 Tools in Education. International Journal of Emerging Technologies in Learning (iJET), 14(22): 70-81. https://doi.org/10.3991/ijet. v14i22.11752

[7] Chip. (2013). Dünyanın En Büyük Web Siteleri. Chip Dergisi Aylık, 24-25.

[8] Rautela, S., \& Sharma, A. (2019). Spirituality and Social Media: Connecting the Dots. International Journal of Interactive Mobile Technologies, 13(9). https://doi.org/10. $\underline{\text { 3991/ijim.v13i09.8863 }}$ 
[9] Çakır, Ö., Kan, A., \& Sünbül, Ö. (2006). Öğretmenlik meslek bilgisi ve tezsiz yüksek lisans programlarının tutum ve özyeterlik açısından değerlendirilmesi. Mersin Üniversitesi Eğitim Fakültesi Dergisi, 2(1): 36-47. https://doi.org/10.17152/gefad.548437

[10] Çakmak, S., Şafak, P., Karakoç, T., Çitil, M., Küçüközyiğit, M.S., Aslan, C., \& Yılmaz, H.C. (2016). Özel eğitim ve yardımcı teknolojiler. Ankara: Vize Yayıncılık

[11] Daher, T., \& Lazarevic, B. (2014). Emerging instructional technologies: Exploring the extent of faculty use of web 2.0 tools at a midwestern community college. TechTrends: Linking Research ve Practice to Improve Learning, 58(6): 42-50. https://doi.org/10.1007/s 11528-014-0802-1

[12] Davulcu, G., \& Tezer, M. (2020). An evaluation of the news about people with disabilities published in the written media. Contemporary Educational Researches Journal, 10(1): 720. https://doi.org/10.18844/cerj.v10i1.4610

[13] DiNucci, D., (1999). Fragmented future, Print, 53(4), 32.

[14] El-Adl, A., \& Alkharusi, H. (2020). Relationships between self-regulated learning strategies, learning motivation and mathematics achievement. Cypriot Journal of Educational Sciences, 15(1): 104-111. https://doi.org/10.18844/cjes.v15i1.4461

[15] Elicin, Ö. (2016). Özel eğitimde teknoloji destekli öğretim. Ankara. Vize Yayıncılık.

[16] Fischer, G. \& Konomi, S. (2005). Innovative media in support of distributed intelligence and lifelong Learning. In Proceedings of the Third IEEE International Workshop on Wireless and Mobile Technologies in Education (pp. 3-10). Los Alamitos, CA: IEEE Computer Society. https://doi.org/10.1109/wmte.2005.35

[17] Garbin, M., Trombeta de Oliveira, E., Pirillo, N., \& Telles, S. (2020). Pedagogical practices based on areas of knowledge: Reflections on the technology use. New Trends and Issues Proceedings on Humanities and Social Sciences, 7(1): 134-141. https://doi.org/10. $\underline{18844 / \text { prosoc.v7i1.4877 }}$

[18] Wardani, I., Tolle, H., \& Aknuranda, I. (2019). Evaluation of an Educational Media on Cube Nets Based on Learning Effectiveness and Gamification Parameters. International Journal of Emerging Technologies in Learning (iJET), 14(14): 4-18. https://doi.org/10.39 91/ijet.v14i14.10505

[19] Guggenberger, B.H. (2008). Attitudes of Indiana special education teachers towards the use and implementation of assistive technology (pp. 1-92). Indiana State University

[20] Hew, K. F., \& Brush, T. (2007). Integrating technology into K-12 teaching and Learning: Current knowledge gaps and recommendations for future research. Educational Technology Research and Development, 55(3): 223-252. https://doi.org/10.1007/s11423006-9022-5

[21] Hsu, Y.-C., Ching, Y.-H., \& Grabowski, B. L. (2014). Web 2.0 applications and practices for learning through collaboration. In M. Spector, D. Merrill, J. Elen, \& M. J. Bishop (Eds.), Handbook of research on educational communications and technology (pp. 747758). New York: Springer. https://doi.org/10.1007/978-1-4614-3185-5_60

[22] Galustyan, O., Vyunova, N., Komarova, E., Shusharina, E., Gamisonija, S., \& Sklyarova, O. (2019). Formation of Media Competence of Future Teachers by Means of ICT and Mobile Technologies. International Journal of Interactive Mobile Technologies (iJIM). 13(11): 184-196. https://doi.org/10.3991/ijim.v13i11.11350

[23] Kim, Y.W., Kim, Y.G., Kim, N.J., \& Woo, Y.G. (2003). A study on the Korea teacher's perception of using assistive technology. Journal of Asia-Pacific Special Education, 3(1): $35-48$.

[24] Korucu, A. T., \& Çakır, H. (2014). Bilgisayar öğretmeni adaylarının dinamik web teknolojilerine yönelik görüşleri. XVI. Akademik Bilişim Konferans1, 5-7. 
[25] Maushak, N.J., Kelley, P., \& Blodgett, T. (2001). Preparing teachers for the inclusive classroom: A preliminary study of attitudes and knowledge of assistive technology. Journal of Technology and Teacher Education, 9(3): 419-431.

[26] Murugaiyan, A., \& Arulsamy, S. (2013). Attitude of student teachers towards integration of assistive technology in inclusive classrooms. International Journal of Teacher Educational Research, 2(4): 1-8.

[27] Nilay, Y., \& Özmen, B. (2012). Video paylaşim sitelerinin eğitsel amaçlı kullanımı. eJournal of New World Sciences Academy, 289.

[28] O'Reilly, T., (2005). What is Web 2.0: Design patterns and business model for the next generation of software, O'Reilly Media. http://www.oreillynet.com/pub/a/oreilly/tim/ news/2005/09/30/whatis-web-20.html

[29] Owen, M., Grant, L., Sayers, S. \& Facer, K. (2006). Social software and Learning. Bristol, England: Futurelab. http://www.futurelab.org.uk/download/pdfs/research/opening education/Social_Software_report.pdf

[30] Özgüç, C.S., \& Cavkaytar, A. (2014). Teacher use of instructional technology in a special education school for students with intellectual disabilities: A case study. Turkish Online Journal of Qualitative Inquiry, 5(1): 47-59. https://doi.org/10.17569/tojqi.14394

[31] Smith, D.W., Kelley, P., Maushak, N.J., Griffin-Shirley, N., \& Lan, W.Y. (2009). Assistive technology competencies for teachers of students with visual impairments. Journal of Visual Impairment \& Blindness, 103(8): 457-469. https://doi.org/10.1177/01454 $\underline{82 \times 0910300804}$

[32] Theodorou, P., \& Meliones, A. (2019). Developing apps for people with sensory disabilities and implications for technology acceptance models. Global Journal of Information Technology: Emerging Technologies, 9(2): 33-40. https://doi.org/10.18844/ gjit.v9i2.4431

[33] Bista, S. K., Nepal, S., Colineau, N., \& Paris, C. (2012, October). Using gamification in an online community. In 8th International Conference on Collaborative Computing: Networking, Applications and Worksharing (CollaborateCom) (pp. 611-618). IEEE. https ://doi.org/10.4108/icst.collaboratecom.2012.250526

[34] Yehya, F. (2020). Creative thinking skills in the Lebanese schools from secondary physics teachers' perspectives. International Journal of Learning and Teaching, 12(2), 115-130. https://doi.org/10.18844/ijlt.v12i2.4718

[35] Yesilyurt, F. (2020). Internet gaming disorder: Remarks of psychiatrists. World Journal on Educational Technology: Current Issues, 12(2): 98-106. https://doi.org/10.18844/wjet.v12 $\underline{\mathrm{i} 2.4813}$

[36] Yücel, Ü. A. (2017). Perceptions of pedagogical formation students about Web 2.0 tools and educational practices. Education and Information Technologies, 22(4): 1571-1585. https://doi.org/10.1007/s10639-016-9508-7

[37] Zaid, M. (2020). Code-switching: The case of "Israeli Arab" students at the Arab American University-Palestine. Global Journal of Foreign Language Teaching, 10(1): 20-31. https:// doi.org/10.18844/giflt.v10i1.4409

[38] Lee, H. M., Chou, M. J., Chin, C. H., \& Wu, H. T. (2017). The Relationship between Psychological Capital and Professional Commitment of Preschool Teachers: The Moderating Role of Working Years. Universal Journal of Educational Research, 5(5): 891900. https://doi.org/10.13189/ujer.2017.050521

[39] Wang, L., Ertmer, P. A., \& Newby, T. J. (2004). Increasing preservice teachers' selfefficacy beliefs for technology integration. Journal of research on technology in education, 36(3): 231-250. https://doi.org/10.1080/15391523.2004.10782414 
[40] Hennink, M., Hutter, I., \& Bailey, A. (2020). Qualitative research methods. SAGE Publications Limited.

[41] Korucu, A. T., \& Çakır, H. (2014). Bilgisayar öğretmeni adaylarının dinamik web teknolojilerine yönelik görüşleri. XVI. Akademik Bilișim Konferansı, 5-7.

[42] Horzum, M. B. (2015). Online Learning StudentsPerceptions of the Community of Inquiry Based on Learning Outcomes and Demographic Variables. Croatian Journal of Education: Hrvatski časopis za odgoj i obrazovanje, 17(2): 535-567. https://doi.org/10.15516/cje.v17 $\underline{\mathrm{i} 2.607}$

\section{$7 \quad$ Authors}

Zehra Ozcinar graduated from Küçük Kaymaklı Teacher Training College, completing a degree in BSc Primary School Teacher in 1991. She graduated from Ankara University; completed a degree in MA Curriculum and Instruction in 1995 and completed PhD in area of Educational Technology in 2003. She is Associate Professor of Educational Technology area in 2012 at Ataturk Teacher Training Academy in North Cyprus. Email: zehra.ozcinar@aoa.edu.tr

Regina G. Sakhieva is $\mathrm{PhD}$ in Education, Associate Professor of the Department of Pedagogy of Higher Education of the Institute of Psychology and Education at Kazan (Volga region) Federal University (18 Kremlyovskaya Street, 420000, Kazan, Russia). Her research interests are related to the methodology of teacher education, educational programs design, content selection. She has more than 100 published papers in Russian and International reputable journals. E-mail: saxievarg@mail.ru

Elena L. Pozharskaya is $\mathrm{PhD}$ in Economics, Associate Professor of the Department of Psychology at Plekhanov Russian University of Economics (36 Stremyannyi Pereulok, 115093, Moscow, Russia). Her main scientific work and professional interests are related to economic psychology, business psychology, human resources psychology, human resources development, professional training, intra-corporate training (determining the need for training of the company's employees - the customer; conducting training; strengthening of training.). Also, she actively develops and implements motivational programs. E-mail: kp-reu@ya.ru, Gerashenkol79@mail.ru

Olga V. Popova is PhD in Law, Associate Professor of the Department of International and Public Law at Financial University under the Government of the Russian Federation (49 Leningradsky prospect, 125993, Moscow, Russia). She has more than 50 published scientific works in Russian and international journals, indexed by Scopus and Web of Science data bases. Her research interests are connected with educational environment problems, educational technologies and economic effectiveness of the educational system. E-mail: Helga-popova@yandex.ru

Mariya V. Melnik is a Doctor of Medicine, Professor of the Department of Urgent and Outpatient Therapy at I.M. Sechenov First Moscow Medical University (Sechenov University) (8 Trubetskaya Street, 119991, Moscow, Russia). She has more than 70 published articles in Russian and International journals. Her research interests are connected with health care education, health care technologies and environmental education. E-mail: melnik.m.v@gmail.com 
Valentin V. Matvienko is $\mathrm{PhD}$ in Philology, Associate Professor of the Department of Theory and History of Journalism of the Faculty of Philology at Peoples' Friendship University of Russia (RUDN University) (6 Miklukho-Maklaya Street, 117198, Moscow, Russia). His research interests for the last decade have been largely concerned with the problems of methodology in education and history of journalism, e-learning environment and comparative education. He has more than 50 articles published in different international journals. E-mail: ambassador79@mail.ru

Article submitted 2020-10-05. Resubmitted 2020-11-11. Final acceptance 2020-11-11. Final version published as submitted by the authors. 